\title{
Insulin Secretion in vitro by the Pancreas of the Chinese Hamster
}

\author{
W. Malaisse, F. Malaisse-Lagae, G.C. Gerritsen, W.E. Dulin and P.H. Wright
}

\begin{abstract}
Indiana University Medical School, Indianapolis, Indiana, and The Upjohn Company, Metabolic Diseases Research, Kalamazoo, Michigan
\end{abstract}

\begin{abstract}
Summary. Insulin secretion by pancreatic tissue in vitro in response to glucose was related to plasma glucose and plasma insulin levels during life, and to the degree of granulation of the islets of Langerhans in 22 normal, 6 diabetic and 8 intermittently glycosuric Chinese Hamsters. Secretion was directly related to the insulin content of the pancreas and to the ratio of insulin to glucose in plasma, irrespective of the metabolic state of the animal, but was lowest in diabetic animals and highest in those with intermittent glycosuria. The relevance of these findings to current theories concerning "prediabetes" is discussed.
\end{abstract}

Sécrétion d'insuline in vitro par le pancréas du hamster chinois.

Résumé. Nous avons mesuré la sécrétion d'insuline du tissu pancréatique in vitro en présence de glucose chez 22 hamsters chinois normaux, 6 diabétiques et 8 ayant montré une glucosurie intermittente. Les valeurs obtenues ont été comparées avec l'hyperglycémie et l'insulinémie de ces mêmes animaux avant leur mort. Nous avons observé que la sécrétion insulinique in vitro était proportionnelle au contenu en insuline du pancréas et au quotient de l'insulinémie divisée par le glucose plasmatique indépendamment de l'état métabolique de l'animal. Pourtant, la sécrétion insulinique in vitro la plus basse a été observée chez les animaux diabétiques, et la plus élevée chez ceux qui avaient présenté une glucosurie intermittente. La relation possible de ces observations avee les théories actuelles du "pré-diabète» est discutée. vitro.

Insulinsekretion des Pankreas chinesischer Hamster in

Zusammenfassung. Die durch Glucose stimulierte Insulinsekretion wurde in vitro am Pankreasgewebe chinesischer Hamster gemessen und mit den Glucose- und Insulin-Plasmaspiegeln derselben Tiere in vivo, sowie mit der Granulierung derer Inselzellen 22 normale, 6 diabetische und 8 zeitweise glykosurischer chinesischer Ham. ster) verglichen. Es bestand eine direkte Korrelation zwischen Insulinsekretion und Insulingehalt des Pankreas, sowie mit dem Verhältnis Insulin/Glucose im Plas. ma, ohne Rücksicht auf den Stoffwechsel-Zustand der Tiere. Die niedrigsten Werte wurden allerdings bei den diabetischen Tieren, und die höchstens bei denjenigen mit zeitweiser Glykosurie beobachtet. Die Bedeutung dieser Resultate in bezug auf bestehende Theorien des ,PreDiabetes" wird diskutiert.

Key-words: Spontaneous diabetes, Chinese hamster, Cricetulus griseus, Pancreas in vitro, Insulin secretion in vitro, Insulin secretion in diabetes, Prediabetes, Preclinical diabetes, Antibodies to insulin.
The incidence of diabetes mellitus in the Chinese Hamster is known to be high [6,7], but little is known of the part played by the pancreatic islets in this syndrome. Using a technique that has been success. fully used for the rat [5], insulin secretion in vitro by small pieces of pancreas from the Chinese Hamster was studied under standard conditions. An attempt was made to correlate the functional and histological characteristics of the pancreatic islets with metabolic abnormalities seen in a group of 36 animals.

\section{Materials and Methods}

Chinese hamsters (Cricetulus griseus). All animals were obtained from a colony bred at the Upjohn Company, Kalamazoo, Michigan. They were maintained in air-conditioned quarters and fed a standard diet (Purina mouse breeder chow; Purina, St. Louis).

For the first experiment, a group of 12 non-diabetic animals (Control $I$ ) was selected at random from the stoak colony, the only criterion for seleation being the complete absence of glucose from the urine in fresh samples tested (glucose oxidase; Testape, Eli Lilly and Company, Indianapolis) every two weeks. In the second experiment, three groups were examined. The first included 6 animals (Diabetic) with histories of heavy glycosuria $(++++$, Testape $)$ detected at weekly intervals for more than 2 months; none of these animals had been treated at any time with insulin. Paired with these diabetic animals with respect to age and sex were 6 animals that had never exhibited glycosuria. In the stock colony, which was examined every two weeks, animals were found that exhibited slight (Trace, Testape) and occasional glycosuria. Eight that had had glycosuria of this type during the previous 7 months constituted a group that we are describing as "intermittently glycosuric". Simultaneously examined with these animals was a small group of 4 Chinese hamsters of the same age and sex that, like animals of Control Group I, had never had glycosuria. These 4 animals and the 6 paired with the diabetic hamsters have been pooled to form the second Control group (Control II). Shown in Table 1 are the sexes and mean ages at the time of use of the animals in each of these 4 groups. Also shown are the incidence, severity and age of onset of glycosuria, the mean blood-sugar concentrations measured under fasting and non-fasting conditions, and the incidence of diabetes and intermittent glycosuria (see above) in families (siblings and parents) from which these animals were chosen.

Experimental procedure. One or two days before use, the animals were carefully tranported to India- 
napolis and housed overnight in individual cages with free access to food and water. On decapitation, blood (ca. $1.0 \mathrm{ml}$ ) was collected and the plasma separated immediately. The pancreas was removed, dissected free of fat and lymph nodes, and divided into 20 to 25 pieces of approximately the same size (ca. $8 \mathrm{mg}$ each); these manipulations took less than 15 minutes and were carried out in buffer cooled with ice. One or two pieces from each animal were fixed in Bouin's fluid for histological examination. The remainder, in groups of 4 pieces, were placed in a bicarbonate-buffered medium $(2.0 \mathrm{ml})$ containing glucose $(30,150,300$ or $500 \mathrm{mg} / 100 \mathrm{ml})$, bovine albumin $(0.5 \%, \mathrm{w} / \mathrm{v}$; Bovine albumin, Fraction V, Sigma Chemical Company, St. Louis, Missouri), and guinea pig anti-insulin serum (GPAIS, Lot No. 270). The media were equilibrated with a mixture of oxygen $(95 \%)$ and carbon
Sections (paraffin) of pancreatic tissue from 30 of the 36 animals were stained with hematoxylin-eosin. aldehyde-fuchsin, and aldehyde-thionine [3,9]. The degrees of granulation in $\beta$-cells of each pancreas were evaluated on an arbitrary scale by two observers on 3 occasions in a "blind" study. Values of " 4 " and " 1 " were respectively alloted to the highest and lowest degrees of granulation. The area occupied by islets within the total area of pancreatic tissue of individual sections (mean area per section $=8$ sq. $\mathrm{mm}$; 30 observations) is expressed as a percentage; a graduated grid ( $1 \mathrm{sq} . \mathrm{mm}$ ) mounted in the eye piece of the microscope was used for this approximate estimation.

\section{Results}

As shown in Table 2, there was no significant difference at the time of death between the plasma-

Table 1. Incidence of diabetic signs in 4 groups of Chinese hamsters

\begin{tabular}{|c|c|c|c|c|}
\hline & Control I & ControlII & $\begin{array}{l}\text { Intermittent } \\
\text { Glycosuric }\end{array}$ & Diabetic \\
\hline Number & 12 & 10 & 8 & 6 \\
\hline $\begin{array}{l}\text { Sex } \\
\text { Age (months) }\end{array}$ & $\begin{array}{l}12 \mathrm{f} . \\
19.0 \pm 1.1\end{array}$ & $\begin{array}{l}7 \mathrm{m.} ., 3 \mathrm{f} . \\
12.1 \pm 1.0\end{array}$ & $\begin{array}{l}8 \mathrm{~m} . \\
13.7 \pm 0.3\end{array}$ & $\begin{array}{l}3 \mathrm{~m} ., 3 \mathbf{f .}, \\
12.0 \pm 1.8\end{array}$ \\
\hline $\begin{array}{l}\text { Glycosuria } \\
\text { qualitative (Testape) } \\
\text { quantitative (mg/24H) } \\
\text { age of onset (months) }\end{array}$ & negative & $\begin{array}{l}\text { negative } \\
4 \pm 1\end{array}$ & $\begin{array}{l}\text { trace } \\
4.6 \pm 0.3\end{array}$ & $\begin{array}{l}++++ \\
1138 \pm 354 \\
2.1 \pm 0.5\end{array}$ \\
\hline $\begin{array}{l}\text { Blood sugar }(\mathrm{mg} / 100 \mathrm{ml}) \\
\text { fasting } \\
\text { non fasting }\end{array}$ & & $\begin{array}{l}100 \pm 3 \\
101 \pm 5\end{array}$ & $\begin{array}{l}112 \pm 4 \\
100 \pm 2\end{array}$ & $\begin{array}{l}158 \pm 15 \\
243 \pm 36\end{array}$ \\
\hline $\begin{array}{l}\text { Familial history } \\
\text { parents + siblings } \\
\text { intermittent glycosuric }(\%) \\
\text { diabetic }(\%)\end{array}$ & $\begin{array}{l}70 \\
10.0 \\
4.3\end{array}$ & $\begin{array}{l}61 \\
8.2 \\
0.0\end{array}$ & $\begin{array}{l}54 \\
27.8 \\
3.8\end{array}$ & $\begin{array}{l}49 \\
16.3 \\
40.8\end{array}$ \\
\hline
\end{tabular}

All observations were made one week or more prior to use of the animals in the present experiments. Qualitative (Testape) tests for glyeosuria were done every week (diabetics) or 2 weeks (other groups); quantitative estimations (total reducing substances; $\mathrm{mg} / 24$ hours) covered a period of 5 days in the case of diabetic hamsters and control animals matched with them. The number of parents and siblings in each group includes those animals used in the present experiments.

dioxide $(5 \%)$; and then incubated at $36^{\circ} \mathrm{C}$ for 90 minutes. Insulin secretion into the medium during this period of incubation was measured by a method that has been described in detail elsewhere [5]; it was equated to the fall in concentration of insulin antibodies in the medium during incubation. Mean rates of insulin secretion are stated (a) with respect to the wet weight of incubated tissue $(\mu \mathrm{U} / \mathrm{mg} / 90$ minutes), and (b) for the whole pancreas of an individual animal when all pieces from that animal were incubated under the same conditions (mU/pancreas/90 minutes). Glucose concentrations in the plasma or blood were estimated with the Autoanalyser (Technicon, Instruments Company, Chauncey, New York) using a modification of the method of HowFMAN [4]. Plasma-insulin estimations were carried out by a modification [2] of the method of Morgan and Lazarow [8]. sugar concentrations of the control (I and II) and intermittent glycosuric animals; those of the diabetic animals were markedly elevated. The mean plasmainsulin concentrations in control, intermittently glycosuric, and diabetic animals were not significantly different from one another.

As shown in Fig. 1, insulin secretion by pieces of pancreas from animals of the first Control group (I) increased as the glucose content of the medium was raised from 30 to $300 \mathrm{mg} / 100 \mathrm{ml}$; no further increase in secretion was observed at a higher glucose concentration $(500 \mathrm{mg} / 100 \mathrm{ml})$. In view of the maximal effect produced under these conditions, the same high glucose concentration (300 $\mathrm{mg} / 100 \mathrm{ml}$ ) was used in all the following experiments. At this concentration, glucose stimulated secretion at the same rates (ca. $25 \mu \mathrm{U} / \mathrm{mg} / 90$ minutes) in the two groups of control 
animals (Table 2, Controls I and II). By contrast secretion occured at a low rate (ca. $7 \mu \mathrm{U} / \mathrm{mg} / 90 \mathrm{~min}$ utes) from tissue of diabetic and at a high rate (ca. 42 $\mu \mathrm{U} / \mathrm{mg} / 90 \mathrm{~min}$ ) from that of intermittently glycosuric animals; both these rates being significantly different pancreas as a whole. Thus secretion by the whole pancreas was elevated in intermittently glycosuric (ca. $6 \mathrm{mU} /$ pancreas $/ 90 \mathrm{~min}$.) and reduced in diabetic (ca. $1 \mathrm{mU} /$ pancreas $/ 90$ minutes) animals as compared with the controls (ca. $4 \mathrm{mU} /$ pancreas $/ 90 \mathrm{~min}$ ). This

Table 2. Islet structure and function in 4 groups of hamsters

\begin{tabular}{|c|c|c|c|c|}
\hline & Control I & Control II & $\begin{array}{l}\text { Intermittent } \\
\text { Glycosuric }\end{array}$ & Diabetic \\
\hline Number & 12 & 10 & 8 & 6 \\
\hline Body weight (g) & & $\begin{array}{l}32.7 \pm 1.2 \\
(10)\end{array}$ & $\begin{array}{l}37.3 \pm 0.2 \\
(8)\end{array}$ & $\begin{array}{l}29.2 \pm 1.5 \\
(6)\end{array}$ \\
\hline \multicolumn{5}{|l|}{ Plasma } \\
\hline Sugar $(\mathrm{mg} / 100 \mathrm{ml}$ ) & $\begin{array}{l}158 \pm 10 \\
(11)\end{array}$ & $\begin{array}{l}139 \pm 6 \\
(10)\end{array}$ & $\begin{array}{l}135 \pm 5 \\
(8)\end{array}$ & $\begin{array}{l}380 \pm 48 \\
(6)\end{array}$ \\
\hline Insulin $(\mu \mathrm{U} / \mathrm{ml})$ & & $\begin{array}{l}171 \pm 22 \\
(10)\end{array}$ & $\begin{array}{l}204 \pm 20 \\
(8)\end{array}$ & $\begin{array}{l}165 \pm 40 \\
(6)\end{array}$ \\
\hline Insulogenic index $(\mu \mathrm{U} / \mathrm{mg})$ & & $\begin{array}{l}123 \\
(10)\end{array}$ & $\begin{array}{l}152 \pm 16 \\
(8)\end{array}$ & $\begin{array}{l}52 \pm 16 \\
(6)\end{array}$ \\
\hline \multicolumn{5}{|l|}{ Pancreas } \\
\hline Weight (mg) & $\begin{array}{l}168 \pm 7 \\
(12)\end{array}$ & $\begin{array}{l}169 \pm 5 \\
(10)\end{array}$ & $\begin{array}{l}157 \pm 7 \\
(8)\end{array}$ & $\begin{array}{l}156 \pm 10 \\
(6)\end{array}$ \\
\hline $\begin{array}{l}\text { Insulin secretion } \\
(\mu \mathrm{U} / \mathrm{mg} / 90 \mathrm{~min})\end{array}$ & $\begin{array}{l}27.9 \\
(40)\end{array} \pm 2.5$ & $\begin{array}{l}23.1 \\
(57)\end{array}$ & $\begin{array}{l}41.6 \pm 3.9 \\
(43)\end{array}$ & $\begin{array}{l}7.4 \pm 1.0 \\
(31)\end{array}$ \\
\hline (mU/pancreas/90 min) & & $\begin{array}{l}3.85 \pm 0.58 \\
(10)\end{array}$ & $\begin{array}{l}6.12 \pm 0.43 \\
(8)\end{array}$ & $\begin{array}{l}1.10 \pm 0.20 \\
(6)\end{array}$ \\
\hline Islets granulation & $\begin{array}{l}2.9 \pm 0.3 \\
(8)\end{array}$ & $\begin{array}{l}2.5 \pm 0.2 \\
(10)\end{array}$ & $\begin{array}{l}3.6 \pm 0.2 \\
(7)\end{array}$ & $\begin{array}{l}1.0 \pm 0.0 \\
(5)\end{array}$ \\
\hline Islets surface (\%) & & $\begin{array}{l}1.0 \pm 0.3 \\
(18)\end{array}$ & $\begin{array}{l}1.4 \pm 0.4 \\
(7)\end{array}$ & $\frac{1.3}{(5)} \pm 0.6$ \\
\hline
\end{tabular}

Mean values ( \pm S.E.M.) refer to the number of animals examined in each group, except where insulin secretion is related to the weight of incubated tissue. Such secretion $(\mu \mathrm{U} / \mathrm{mg} / 90 \mathrm{~min})$ was calculated from observations made in individual flasks (n), enough pancreatic tissue being obtained from each animal to be distributed into 5 to 6 flasks.

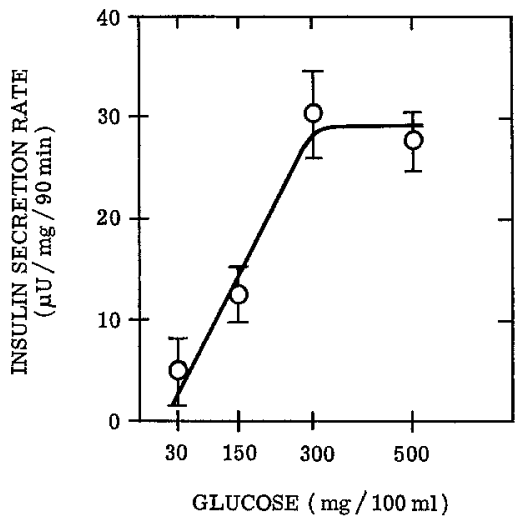

Fig. 1. Mean rates of insulin secretion $(\mu \mathrm{U} / \mathrm{mg} / 90 \mathrm{~min} .+$ S.E.M. $)$ b pancreatic tissue from "normal" Chinese Hamsters (Control I) incubated for 90 minutes in media containing glucose in various concentrations. Also shown is the number of observations made at each glucose concentration

$(p<0.005)$ from that observed in the Control groups. Not only was insulin secretion abnormal in these two groups of animals when related to the weight of incubated tissue but also when it was referred to the finding, as seen in Table 2 , is understandable in view of the fact that the mean weights of the pancreases obtained from these three groups of animals were not significantly different.

Striking differences were seen in the degrees of granulation in the islets of Langerhans of these animals (Fig. 2). Poor granulation was invariably found in the islets of diabetic hamsters. Compared with the control animals, hamsters with intermittent glycosuria showed more marked granulation in the $\beta$-cells (Table 2). The areas occupied by islets in sections of pancreatic tissue in the three groups of animals were not significantly different. If degree of granulation is proportional to the actual insulin content of an islet, this means that the insulin content of the pancreas of the diabetic hamster is reduced and that of animals with intermittent glycosuria is increased. Also noted were moderate interlobular and peri-vascular lymphocytic infiltration of the exocrine tissues and, in some cases, slight interstitial edema. About one third of the animals were affected in this way, but incidence of these lesions was approximately the same 
in control, diabetic, and intermittently glycosuric hamsters.

As shown in Fig. 3, there is a direct correlation $(r=+0.633, p<0.01)$ between the degree of granulation of the islets and insulin secretion stimulated in vitro by glucose at a concentration of $300 \mathrm{mg} / 100$ $\mathrm{ml}$. There is also a direct correlation $(r=+0.589, p<0.01)$ between pancreatic insulin secretion evoked in vitro and the ratio of insulin to glucose found in the plasma at the time of death (Fig. 4).

\section{Discussion}

Amongst the animals which have been used in the study of diabetes mellitus is the Chinese hamster in which the disease develops spontaneously and in a genetically determined manner. In this experimental form of the disease, as in human diabetes, the insulin content of the pancreas is reduced [2], and there is a concomitant reduction in granularity of the $\beta$-cells [6]. This suggests that reduced availability of insulin

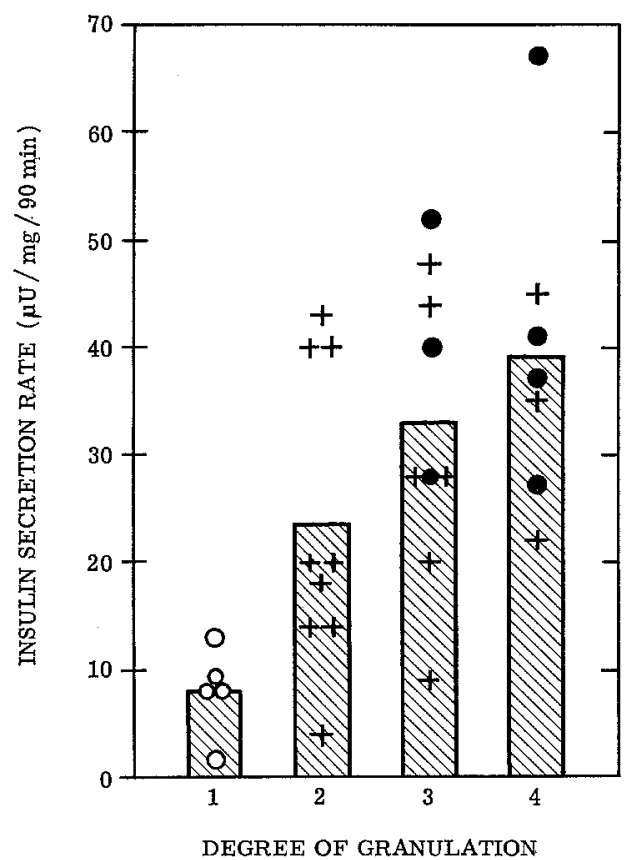

Fig. 3. Relationship between the rate of insulin secretion $(\mu \mathrm{U} / \mathrm{mg} / 90 \mathrm{~min}$. stimulated by glucose $(300 \mathrm{mg} / 100 \mathrm{ml})$ in pancreatic tissue from "normal" (Controls I and II; crosses), intermittently glycosuric (elose circles), and diabetic (open circles) hamsters, and the degree of granulation of the $\beta$-cells. The shaded columns indicate the mean value of insulin secretion for each degree of granulation

may be partly responsible for the appearance of diabetes in these animals. This possibility was investigated in the present experiments.
The animals examined here were selected on the basis of their "clinical" histories, and especially of the incidence and severity of glycosuria, and were divided into three clearly defined groups. Compared with the

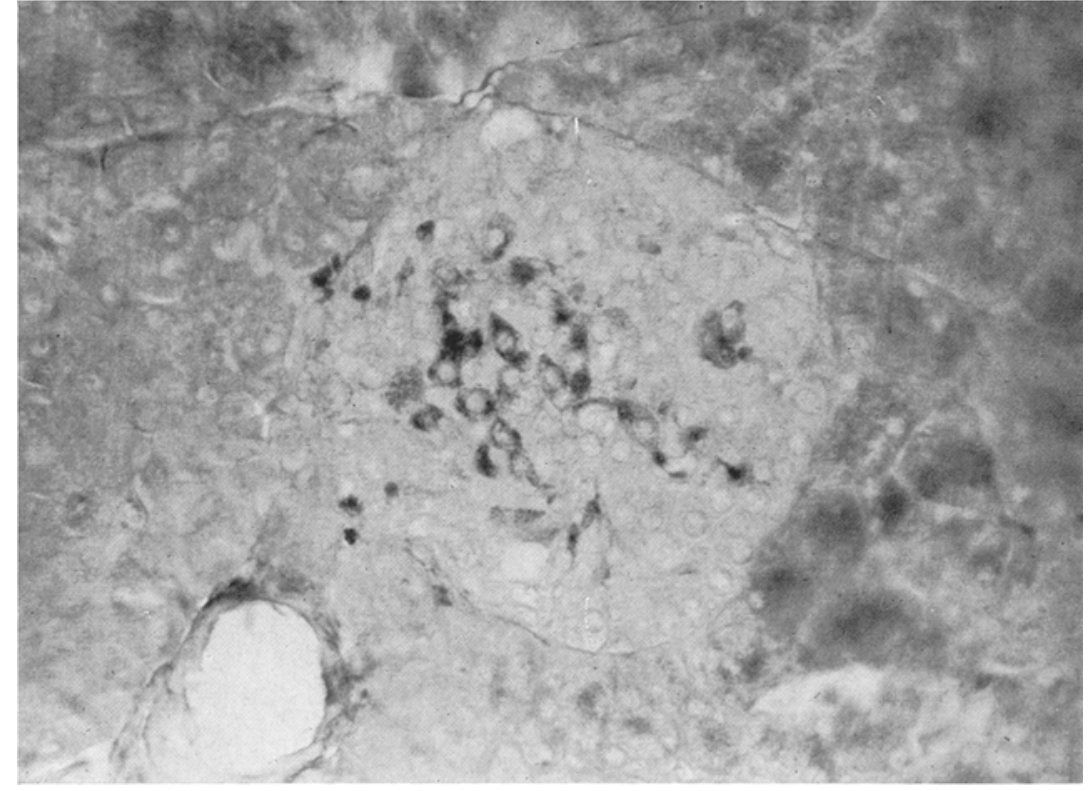
Fig. 2. Granulation in islets of Langerhans from a diabetic (left) and intermittently glycosuric (right)
Chinese hamster. These are examples of poor ("1') and heavy ("4") granulation (magnification, $350 \times$; aldehyde-fuchsin)

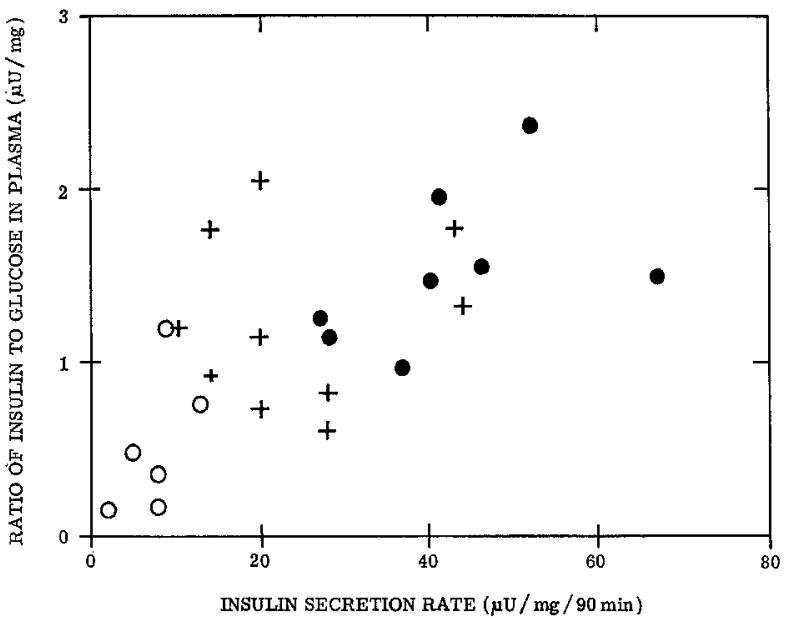

Fig. 4. Relationship between the ratio of insulin to glucose ( $\mu \mathrm{U} / \mathrm{mg}$ ) in plasma and the rate of insulin secretion ( $\mu \mathrm{U} / \mathrm{mg} / 90 \mathrm{~min}$ ) by pancreatic tissue in vitro. Pancreatic tissue from "normal" (Control II, crosses), intermittently glycosuric (close circles), and diabetic (open circles) Chinese Hamsters was incubated in media containing the same concentration of glucose $(300 \mathrm{mg} /$ $100 \mathrm{ml}$ )

"normal" animals (Controls I and II), the diabetic hamsters were hyperglycemic and had a history of persistent heavy glycosuria but they had "normal" levels of circulating insulin. Apart from slight and intermittent glycosuria, which formed the sole basis of their selection, there was nothing to distinguish the third group (Intermittent glycosuric) from either of the control groups. When pieces of pancreatic tissue from these three groups of hamsters were incubated 
with glucose in the same concentrations, other clearly defined differences became apparent. Tissue from the diabetic animals secreted less insulin than the normal tissue in response to the same concentration of glucose.

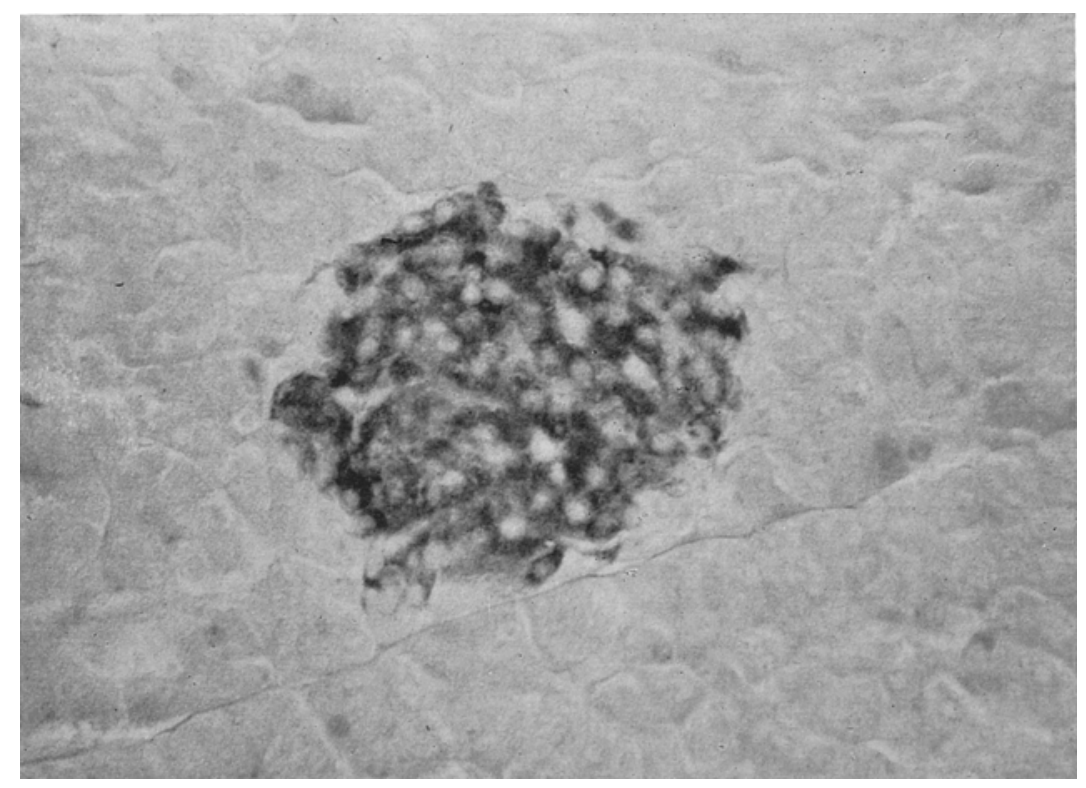

Fig. 2. (right)

In contrast, tissue from the intermittently glycosuric hamsters secreted significantly more. Moreover, a direct correlation was established between insulin secretion evoked in vitro and the degree of granulation found in the $\beta$-cells, irrespective of the condition of the animal from which the pancreatic tissue was removed. These findings, taken in conjunction with others made in diabetic hamsters and in human diabetics, form the basis of the following speculative suggestions.

The syndrome seen in the diabetic hamsters used in the present experiments, and there were only six, has features in common with human diabetes of maturity onset. They had lived for many months without injections of insulin and had shown no tendency to become ketotic. Their plasma also contained "normal" amounts of insulin. Absolute insulin deficiency, in the sense that it occurs in the human diabetes of "juvenile onset" was thus not seen in the present animals. However, the experimental findings reported here suggest that the appearance of diabetes is related to inadequate amounts of stored insulin and reduced responsiveness of the islet tissue to glucose. Reduced storage and secretion of insulin might be secondary to reduced synthesis of the hormone in the $\beta$-cells.

The present observations support a hypothesis put forward by Sectzer and HarRis [10]. They have recently suggested that, among other factors, a reduced reserve of pancreatic insulin is responsible for mild diabetes in the adult human subject and they have used their "insulogenic index", the ratio of insulin to glucose in plasma, to show this. The present experiments clearly show that this "insulogenic index" is directly related to insulin secretion that can be evoked in vitro by glucose. It therefore appears that reduced quantities of stored insulin and impaired responsiveness of the $\beta$-cell to glucose are common features of islet function in these animals and human diabetia subjects.

The intermittently glycosuric animals exhibited features suggestive of "prediabetes" in man. An abnormally large store of pancreatic insulin was associated with an increased response of the pancreatic tissue to glucose, both phenomena suggesting that the pancreas of this type of hamster is equipped to supply increased demands for the hormone. However, until more is known about the genetic basis for the appearance of diabetes in hamsters, it cannot be affirmed that the present intermittently glycosuric animals were "prediabetic" in the sense in which this term is applied to the human syndrome.

One could postulate that the hamster that eventually becomes diabetic may pass through the same intermediate stages suspected to characterize the onset of human diabetes [1]. When subjected to a persistent strain, the pancreas first responds by increasing its store of pancreatic insulin and can secrete more insulin in response to a given stimulus. This is occasionally insufficient and slight transient glycosuria results. At some stage this response becomes permanently impaired, either because synthesis fails or because it cannot be increased further, and the hamster become hyperglycemic and persistently glycosuric. If this is the mechanism by which the relative insulin deficiency develops, then one might expect that the "insulogenic index" would first rise in the "pre-diabetic" phase, and then fall. To test the hypothesis, many more experiments will have to be done and much more will have to be learned about the genetic basis of the disease; but the present findings suggest that much can be learned from repeated estimations of the "insulogenic" index amongst animals that are likely to develop the disease.

Acknowledgements. The authors wish to acknowledge grants in aid of this research (PHS AM 07211-03) and for a Postdoctoral Fellowship (1 F05-TW-865-01) for one of us (W.M.).

\section{References}

[1] CoNn, J.W., and S.S. FAJANS: The prediabetic state. A concept of dynamic resistance to a genetic diabetogenic influence. Amer. J. Med. 31, 839-850 (1961).

[2] GERRITSEN, G.C., and W.E, Dulin: Characterization of diabetes in the Chinese hamster. Diabetologia 3, 74-84 (1967). 
[3] Gomorr, G.: Aldehyde fuchsin: A now stain for elastic tissue. Amer. J. clin. Path. 20, 665-666 (1950).

[4] Hoffman, W.S.: Rapid photoelectric method for the determination of glucose in blood and urine. $J$. biol. Chem. 120, 51-55 (1937).

[5] Malarsse, W., F. Malaisse-Lagae and P.H. WRIGIT: A new method for the measurement of in vitro pancreatic insulin secretion. Endocrinology 80, 99-108 (1967).

[6] Meter, H., and G. E. YkrgantaN : Spontaneous hereditary diabetes mellitus in Chinese hamster. Pathological findings. Proc. Soc. exp. Biol. 100, $810-815$ (1959).

[7] - - Spontaneous diabetes mellitus in the Chinese Hamster. Diabetes 10, 12-21 (1961).
[8] Morgars, C.R., and A. Lazarow: Immunoassay of insulin: two antibody system. Diabetes 12, 115-126 (1963).

[9] Paget, G.E.: Aldehyde-thionin: a stain having similar properties to aldehyde fuchsin. Stain Technol. $34,223-226$ (1959).

[10] Skitzer, H.S., and V.L. HarRis : Exhaustion of In. sulogenic Reserve in Maturity-onset Diabetic Patients during prolonged and continuous Hyperglycemic stress. - Diabetes 13, 6-13 (1964).

Dr. Wirly Maraisse

Indiana University

Medical School

Department of Pharmacology

1100 West Michigan Street

Indianapolis, Indiana 46207

U.S.A. 